\title{
Apolipoprotein E (apoE) delivery by peritoneal implantation of encapsulated recombinant cells improves the hyperlipidaemic profile in apoE-deficient mice
}

\author{
Aristides D. Tagalakis ${ }^{\mathrm{a}, \mathrm{b}}$, Ivan A. Diakonov ${ }^{\mathrm{a}}$, Ian R. Graham ${ }^{\mathrm{b}}$, Karen A. Heald ${ }^{\mathrm{c}}$, \\ Julian D. Harris ${ }^{\mathrm{b}}$, Jane V. Mulcahy ${ }^{\mathrm{a}}$, George Dickson ${ }^{\mathrm{b}}$, James S. Owen ${ }^{\mathrm{a},{ }^{*}}$ \\ ${ }^{\mathrm{a}}$ Department of Medicine, Royal Free and University College Medical School, University College \\ London, Royal Free Campus, London NW3 2PF, UK \\ ${ }^{\mathrm{b}}$ Division of Biochemistry, School of Biological Sciences, Royal Holloway University of London, \\ Egham, Surrey TW20 OEX, UK \\ 'Islet Research Laboratory, Department of General Surgery, Worcester Royal Infirmary, Worcester \\ WR1 3AS, UK \\ * Corresponding author: James S. Owen, Department of Medicine, Royal Free and University \\ College Medical School, Rowland Hill Street, London NW3 2PF, UK. \\ Tel: + 44-20-7433-2853; Fax: + 44-20-7433-2852 \\ E-mail address: j.owen@rfc.ucl.ac.uk (J.S. Owen)
}

Keywords: atherosclerosis; cholesterol; gene transfer; hypercholesterolaemia; lipoproteins 


\section{Abstract}

Plasma apolipoprotein E (apoE) is a 34-kDa polymorphic protein, which has atheroprotective actions by clearing remnant lipoproteins and sequestering excess cellular cholesterol. Low or dysfunctional apoE is a risk factor for hyperlipidaemia and atherosclerosis, and for restenosis after angioplasty. Here, in short-term studies designed to establish proof-of-principle, we investigate whether encapsulated recombinant Chinese hamster ovary (CHO) cells can secrete wild-type apoE3 protein in vitro and then determine whether peritoneal implantation of the microcapsules into apoE-deficient (apoE ${ }^{-/}$) mice reduces their hypercholesterolaemia.

Recombinant CHO-E3 cells were encapsulated into either alginate poly-L-lysine or alginate polyethylenimine/polybrene microspheres. After verifying stability and apoE3 secretion, the beads were then implanted into the peritoneal cavity of apoE $E^{-/-}$mice; levels of plasma apoE3, cholesterol and lipoproteins were monitored for up to 14 days post-implantation.

Encapsulated CHO-E3 cells continued to secrete apoE3 protein throughout a 60-day study period in vitro, though levels declined after 14 days. This cell-derived apoE3 was biologically active. When conditioned medium from encapsulated CHO-E3 cells was incubated with cultured cells pre-labelled with $\left[{ }^{3} \mathrm{H}\right]$-cholesterol, efflux of cholesterol was 2-4 times greater than with normal medium (at $8 \mathrm{~h}$, for example, $7.4 \pm 0.3 \%$ vs. $2.4 \pm 0.2 \%$ of cellular cholesterol; $P<0.001)$. Moreover, when secreted apoE3 was injected intraperitoneally into apoE ${ }^{-/}$mice, apoE3 was detected in plasma and the hyperlipidaemia improved. Similarly, when alginate polyethylenimine/polybrene capsules were implanted into the peritoneum of apoE ${ }^{-/-}$mice, apoE3 was secreted into plasma and at 7 days total cholesterol was reduced, whilst atheroprotective highdensity lipoprotein (HDL) increased. In a second study, apoE was detectable in plasma of 5 mice treated with alginate poly-L-lysine beads, 4 and 7 days post-implantation, though not at day 14. Furthermore, their hypercholesterolaemia was reduced, while HDL was clearly elevated in all mice at days 4 and 7 (from $18.4 \pm 6.2 \%$ of total lipoproteins to $31.1 \pm 6.8 \%$ at 7 days; $P<0.001$ ); however, these had rebounded by day 14, possibly due to the emergence of anti-apoE antibodies.

We conclude that microencapsulated apoE-secreting cells have the potential to ameliorate the hyperlipidaemia of apoE deficiency, but that the technology must be improved to become a feasible therapeutic to treat atherosclerosis. 


\section{Introduction}

Plasma apolipoprotein (apo) $\mathrm{E}$ is a $34-\mathrm{kDa}$ polymorphic protein with several anti-atherogenic actions, including the clearance of remnant lipoproteins and promotion of cholesterol efflux from cells [1,2]. The common dysfunctional isoforms, apoE2 (C112, C158) and apoE4 (R112, R158), differ in two amino acid positions from the most prevalent or wild-type protein, apoE3 (C112, R158), and produce recessive (Type III) and dominant hyperlipidaemias, respectively [2,3]. ApoE4 is also a risk factor for restenosis [4] and smoking-related heart disease [5]. Infusing apoE into hypercholesterolaemic rabbits regresses atherosclerotic lesions [6], while apoE transgenic mice resist dietary or diabetic hyperlipidaemia [7,8]. In contrast, apoE-deficient mice (apoE ${ }^{-/}$) have gross hyperlipidaemia with elevated very-low- (VLDL), intermediate- (IDL) and low-density lipoproteins (LDL) and develop spontaneous atherosclerosis [9].

Although considerable progress has been made in the prevention and treatment of atherosclerosis, new approaches are still needed. These include systemic gene therapy to overexpress proteins that directly or indirectly inhibit atherogenesis and/or stabilize susceptible lesions. Indeed, the principle of apoE gene transfer to treat dyslipidaemia and atherosclerosis using adenoviral vectors is already established by several laboratories, including our own [10]. However, non-viral transfer strategies have been relatively neglected [11-13].

One approach to deliver therapeutic proteins is to encapsulate genetically engineered cells within semi-permeable membranes. Alginate mixed with certain polymers is widely used to produce capsules and is a cheap and accessible technology for non-specialized laboratories. The microcapsules have good biocompatibility and their pore size, which can be manipulated, allows nutrients to enter while excluding T-lymphocytes or antibody infiltration [14-21]. Potentially, this cell-therapy approach circumvents several problems associated with alternative systems, including inefficient gene transfer or a failure to sustain gene expression. In the present study, we encapsulate recombinant cells expressing human apoE3 into alginate-based microspheres and confirm in vitro that apoE3 protein is secreted and is biologically active. Moreover, when the capsules were implanted into the peritoneal cavity of apoE $\mathrm{E}^{-/-}$mice, apoE was readily detected in plasma and reduced total cholesterol levels, while increasing anti-atherogenic high-density lipoprotein (HDL). We conclude that implantation of encapsulated apoE3-secreting cells can potentially reverse hyperlipidaemia. However, the technology must be improved and refined before routine use, particularly for long-term use to help retard or regress atherosclerosis. 


\section{Materials and methods}

\subsection{Recombinant cells secreting human apoE3}

Chinese hamster ovary cells were stably transfected with human apoE3 cDNA (CHO-E3 cells) using the p7055 high-expression vector, which contains the selectable marker gene, dihydrofolate reductase (DHFR) [22]. The CHO-E3 cells were cultured in humidified $5 \% \mathrm{CO}_{2}$ at $37{ }^{\circ} \mathrm{C}$ in Iscove's modified DMEM media supplemented with $2 \mathrm{mM}$ glutaMAX, $100 \mathrm{U} / \mathrm{ml}$ penicillin, 100 $\mu \mathrm{g} / \mathrm{ml}$ streptomycin, 1\% non-essential amino acids (all from Life Technologies; henceforth termed 'Iscove’s medium’) and 10\% dialysed fetal bovine serum (FBS, Sigma), but lacking hypoxanthine and thymidine. Conceivably, gene loss or silencing could ensue when the encapsulated CHO-E3 cells are implanted into mice, as selection pressure on the DHFR gene is absent. However, this was not observed when a DHFR-containing construct was used to express a neurotrophic factor [23]; nor did it occur when we cultured CHO-E3 cells in non-selection medium (unpublished data).

\subsection{ApoE3 protein preparation and injection into apoE-deficient mice}

To prepare apoE3 protein for injection, recombinant CHO-E3 cells were cultured for $72 \mathrm{~h}$ in serumfree CD-CHO medium (Life Technologies) and the media concentrated and dialysed against PBS by ultrafiltration (VIVASPIN, 30,000 MWCO; Vivascience). Aliquots containing $50 \mu \mathrm{g}$ apoE3 were sterile-filtered and snap-frozen in liquid nitrogen for storage at $-80^{\circ} \mathrm{C}$. Although such preparations may contain some CHO-derived proteins $>30-\mathrm{kDa}$, we did not attempt to purify the apoE further, since there is good evidence that this can reduce bioactivity [24,25]. Two groups of adult female apoE $\mathrm{E}^{-/}$mice (10-12 weeks old; provided by GlaxoSmithKline, Stevenage, UK) [9,13]) were given intraperitoneal injections of $50 \mu \mathrm{g}$ apoE3 in $200 \mu \mathrm{l}$ PBS. The first group (n=3) was injected once, followed by tail-bleeds at 1, 2, 4 and $24 \mathrm{~h}$, while the second $(\mathrm{n}=3)$ was injected daily for 4 days with tail bleeds on day 2 and day 5 (termination). Control mice received PBS alone. Blood was clotted on ice for 2-3 h and the serum stored at $-80^{\circ} \mathrm{C}$ for subsequent analyses.

\subsection{Microencapsulation and characterization of alginate beads}

Sodium alginate was purchased from Kelco International (Manugel; mannuronic:guluronic ratio of 1) and purified further by charcoal filtration, while coating reagents were from Sigma-Aldrich. Noncoated alginate (Alg) beads were prepared by suspending CHO-E3 cells (4-12 x 10 cells) in $3 \mathrm{ml}$ of $1.5 \%$ purified alginate and 3.6\% sorbitol and extruding droplets with a concentric airflow through a $23 \mathrm{G}$ needle at $1.5 \mathrm{ml} / \mathrm{min}$ into a gelling solution of $0.1 \mathrm{M} \mathrm{CaCl}_{2}$ in $0.15 \mathrm{M} \mathrm{NaCl}, \mathrm{pH}$ 7.4. These beads were used to make two types of coated beads. The first were coated with polyethyleneimine 
(PEI ) and polybrene (PB, hexadimethrine bromide) by washing the beads in 3.6\% sorbitol, 0.33\% methylcellulose (tylose $\mathrm{MH}$ 1000) and $10 \mathrm{mM}$ HEPES for 2-3 min and then adding PEI/PB stepwise with stirring to final concentrations of $0.1 \%$ and $0.05 \%$, respectively. After further washing, $3 \%$ alginate was added to a final concentration of $0.03 \%$ and, following successive washes with sterile water and Iscove's medium, the beads were transferred to culture flasks. The second set of beads was coated with poly-L-lysine (PLL, 30-70 kDa) at a final concentration of $0.05 \%$ in 0.15 $\mathrm{M} \mathrm{NaCl}$. The microcapsules were washed 3 times in calcium-free Krebs-Ringer buffer (KRB), incubated in alginate (0.2\%) for $5 \mathrm{~min}$ and then in $1 \mathrm{mM}$ EGTA for $10 \mathrm{~min}$, before washing in KRB and suspension in Iscove's medium.

Both Alg-PEI/PB and Alg-PLL beads were characterized further. Mechanical stability was assessed by preparing coated and uncoated beads in 1\% blue-dextran (2,000 kDa, Amersham Plc) and then shaking overnight with $500 \mu \mathrm{m}$ diameter glass balls. Absorbance of the supernatants was measured at $620 \mathrm{~nm}$. To measure cell proliferation the beads were first disrupted by incubation with $0.02 \%$ EDTA for $20 \mathrm{~min}$ at $37^{\circ} \mathrm{C}$ and passage through a $23 \mathrm{G}$ needle and the liberated cells collected by brief centrifugation. Cell nuclei were isolated by incubation with $0.01 \%$ Triton X-100 in PBS for $18 \mathrm{~h}$ at $4{ }^{\circ} \mathrm{C}$, stained with propidium iodide and counted under a fluorescent microscope (Nikon Eclipse TE 200). Finally, we measured apoE3 secretion and cell leakage from encapsulated cells by culturing the beads in nylon mesh strainers (BD Falcon) within 6-well plates. At regular intervals, the supernatant was collected to measure $24 \mathrm{~h}$ secretions of apoE3, while any cells escaping from the beads and becoming adherent were dissolved in $0.1 \mathrm{M} \mathrm{NaOH}$ and quantified by protein assay (Bradford reagent; Bio-Rad Laboratories).

\subsection{Cholesterol efflux}

The bioactivity of apoE3 secreted from capsules was examined by measuring their ability to promote cellular cholesterol efflux [26]. Wild-type CHO cells were seeded overnight in 12-well plates ( $2 \times 10^{5}$ cells/well) and labelled by incubating for $24 \mathrm{~h}$ in $1 \mathrm{ml}$ Iscove's medium supplemented with 5\% FBS and $1 \mu \mathrm{Ci}\left[{ }^{3} \mathrm{H}\right]$-cholesterol. The cells were then equilibrated overnight in Iscove's medium plus $1 \%$ fatty acid-free albumin and cholesterol efflux initiated by adding conditioned CD-CHO medium from encapsulated CHO-E3 cells ( $1 \mathrm{ml}$; 24 h collection) for 2, 4 or 8 h; medium from wild-type cells was used as control. At each time point, efflux medium was collected, centrifuged for $1 \mathrm{~min}$ at $10,000 \mathrm{~g}$ and an aliquot taken for $\left[{ }^{3} \mathrm{H}\right]$ measurement, while the cell monolayers were dissolved in $0.1 \mathrm{M} \mathrm{NaOH}$ to quantify cellular $\left[{ }^{3} \mathrm{H}\right]$-cholesterol. The percentage cholesterol efflux was calculated as $\mathrm{dpm}_{\text {medium }} /\left(\mathrm{dpm}_{\text {medium }}+\mathrm{dpm}_{\text {cells }}\right) \mathrm{x} \mathrm{100 \%}$. 


\subsection{Intraperitoneal implantation of encapsulated CHO-E3 cells}

In a pilot experiment, three mice (mice 1-3) received intraperitoneal injections of $\sim 9 \times 10^{6}$ cells encapsulated in Alg-PEI/PB beads $(900 \mu \mathrm{l})$. In the second study, 5 mice (mice A-E) were injected with $\sim 10 \times 10^{6}$ cells in $900 \mu$ l of Alg-PLL beads, while 5 control mice (mice a-e) received empty beads. All animals were killed one or two weeks post-implantation by $\mathrm{CO}_{2}$ inhalation. In some cases, beads were retrieved by washing the peritoneal cavity with sterile saline and then were cultured for 10 days to verify their integrity and to confirm continuous secretion of apoE3.

\subsection{Lipid analyses of mouse serum}

Lipoproteins in serum $(2 \mu \mathrm{l})$ were separated by electrophoresis in Sebia alkaline-buffered agarose gels (YSI, Farnborough, UK), measuring relative concentrations by scanning densitometry (BioRad GS-670 with Molecular Analyst Version 1.4 software) after Sudan Black staining [10]. Total cholesterol was assayed in 96-well plates (INFINITY cholesterol reagent; Sigma-Aldrich).

\subsection{Detection of human apoE and anti-apoE antibodies in mouse serum}

Human apoE3 secreted into serum of apoE $\mathrm{E}^{-/-}$mice was detected by Western blotting and quantified by a two-antibody sandwich ELISA, both as described previously [10]. To detect any anti-human apoE antibodies, human apoE3 (1 $\mu \mathrm{g} / \mathrm{lane}$ ) was transferred to Hybond-PVDF membranes by Western blotting and individual lanes hybridized with $2.5 \mu \mathrm{l}$ of test mouse serum in $600 \mu \mathrm{l}$ of buffer containing $2.5 \%$ milk powder and $0.05 \%$ Tween 20 . Detection was with a goat anti-mouse-HRP secondary antibody using a mouse monoclonal antibody against human apoE3 as a positive control.

\subsection{Statistics}

Results are expressed as means \pm S.D. Statistical differences between means were analyzed by Student's paired or unpaired $t$-test, as appropriate; $P<0.05$ was considered significant.

\section{Results}

\subsection{ApoE3 injections into apoE $E^{-/-}$mice}

Human apoE3 protein (Materials and methods) was injected into the peritoneal cavity of two groups of apoE $\mathrm{E}^{-/-}$mice. The first group $(\mathrm{n}=3)$ received a single injection of $50 \mu \mathrm{g}$. At $1 \mathrm{~h}$ apoE3 was readily detected in serum, appeared to have peaked at about $6 \mu \mathrm{g} / \mathrm{ml}$ by $4 \mathrm{~h}(2 / 3$ mice having less apoE3 at $4 \mathrm{~h}$ than $2 \mathrm{~h}$ ), and at $24 \mathrm{~h}$ had declined markedly to $<5 \%$ of the peak value (Fig. 1a). The second group 
$(\mathrm{n}=3)$ received daily injections of $50 \mu \mathrm{g}$ apoE3 for 4 days, collecting blood just prior to injections at 0 and 2 days, and at termination, 24 h post-injection (5 days). At 2 days, serum apoE3 was about 0.8 $\mu \mathrm{g} / \mathrm{ml}$ but $\sim 30 \%$ lower at 5 days (Fig. 1b). However, serum cholesterol was significantly reduced in the treated mice at termination, falling from $523 \pm 40 \mathrm{mg} / \mathrm{dl}$ to $399 \pm 18 \mathrm{mg} / \mathrm{dl}(P<0.05)$ (Fig. 1c). In addition, when the individual lipoprotein fractions were analysed by agarose gel electrophoresis there was a significant increase $(P<0.05)$ in the proportion of atheroprotective HDL present (Fig. $1 \mathrm{~d})$.

\subsection{Secretion of human apoE3 from encapsulated CHO-E3 cells in vitro}

Recombinant CHO-E3 cells were encapsulated into Alg-PEI/PB beads or uncoated beads at a density of $12 \times 10^{6}$ cells/ $\mathrm{ml}$ alginate and cultured for 10 days. ApoE3 was secreted continuously at an approximately constant rate from both types of beads, suggesting that the cross-linking polymeric coating did not impair secretion (Fig. 2a). In a second study, Alg-PLL beads containing CHO-E3 cells at an initial density of $4 \times 10^{6}$ cells/ml alginate were cultured for 2 months; the cells remained viable and secreted apoE3 throughout the study period. However, while the amount of secreted apoE3 increased steadily for the first 2 weeks, peaking at nearly $1 \mu \mathrm{g} / \mathrm{ml} / 24 \mathrm{~h}$, it declined thereafter to $<0.1 \mu \mathrm{g} / \mathrm{ml} / 24 \mathrm{~h}$ at 8 weeks (Fig. 2b).

The ability of CHO-E3 cells to proliferate post-encapsulation was studied and also bead stability itself. As judged by counting isolated nuclei in $1 \mathrm{ml}$ beads, CHO-E3 cells were capable of $\sim 6$-fold proliferation. Thus, in uncoated beads cell numbers (x $\left.10^{-5}\right)$ increased from $2.6 \pm 0.1$ at day 0 to $17.4 \pm 1.2$ at day 10 , while the corresponding increases for coated Alg-PLL beads were from $5.1 \pm 0.2$ to $14.5 \pm 0.9$ and for Alg-PEI/PB beads from 5.2 \pm 0.2 to 20.1 \pm 0.2 . Mechanical stability was assessed by leakage of encapsulated blue dextran in an abrasion test. As this high molecular weight polymer cannot diffuse out of intact beads, its appearance in the supernatant following agitation of the microcapsules with glass balls reflects bead rupture. As shown in Fig. 2c, uncoated beads were much more fragile $(P<0.001)$, whereas coated beads readily withstood the test with no clear difference between them $(P>0.05)$. To evaluate the long-term stability of beads in culture, the protein content of leaked cells, which form colonies on the surface of the plate, was measured after 10 days. The cell protein leaked from uncoated beads was 68.7 $\pm 3.1 \mu$ g, whereas the coated Alg-

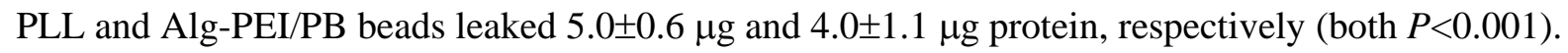

\subsection{Encapsulated CHO-E3 cells secrete biologically active human apoE3}

To verify that the apoE3 secreted by encapsulated cells was biologically active, cholesterol efflux

experiments were undertaken. Wild-type $\mathrm{CHO}$ cells were radiolabelled with $\left[{ }^{3} \mathrm{H}\right]$-cholesterol and 
incubated with conditioned serum-free CD-CHO medium from encapsulated CHO-E3 cells, containing $624 \pm 3.1 \mathrm{ng}$ of secreted apoE3. At each time studied, 2, 4 and $8 \mathrm{~h}$, the capsuleconditioned medium promoted 2-4 times more cholesterol efflux than control medium; at $8 \mathrm{~h}$, for example, $7.4 \pm 0.3 \%$ of cell cholesterol was effluxed compared to $2.4 \pm 0.2 \%(P<0.001)$ (Fig. $2 \mathrm{~d})$.

\subsection{Intraperitoneal implantation of encapsulated CHO-E3 cells}

In the pilot study, CHO-E3 cells encapsulated in Alg-PEI/PB beads were cultured for 1 day and then implanted into the peritoneal cavity of three $\mathrm{apoE}^{-/-}$mice (mice 1-3), collecting tail blood at days 2, 4 and 7. In two animals (mice 2 and 3), apoE3 was detected in serum (35-80 ng/ml) throughout the study (Fig. 3a), and on day 7 their serum cholesterol had fallen by $13 \%$ and 19\%, respectively (Fig. 3b). In contrast, no apoE was detected in the serum of mouse 1 and its cholesterol level was slightly raised. Analysis of the lipoproteins by agarose gel electrophoresis revealed that the proportion of HDL had risen in mice 2 and 3, but was unchanged in mouse 1 (Fig. 3c). Microcapsules were harvested from animals at 7 days post-implantation, re-cultured for 10 days and then the media analyzed for human apoE3 by Western blotting. All were positive, although mouse 1 gave a weak signal compared to mice 2 and 3 (Fig. 3d).

In a second experiment, CHO-E3 cells were encapsulated in Alg-PLL beads and, following culture in vitro for 3 days, were implanted into five apoE $E^{-/-}$mice, collecting tail bloods on days 4, 7 and 14; five control mice received empty capsules. ApoE3 was present in the serum of treated mice on days 4 and 7 at levels of $83 \pm 9$ and $153 \pm 14 \mathrm{ng} / \mathrm{ml}$, respectively, but was undetectable by day 14 (Fig. 4a). Western blots also confirmed the presence of human apoE3 in mouse serum at days 4 and 7 only (Fig. 4b). Consistent with these data, mean serum cholesterol levels decreased significantly on days 4 and $7(P<0.001$ and $P<0.01$, respectively; Fig. 4a), whereas agarose gel lipoprotein analysis revealed significant rises in the proportion of $\operatorname{HDL}(P<0.05$ and $P<0.05$, respectively; Fig. 4c); these both rebounded to pre-implantation levels at day 14 (Fig. 4a,c). Finally, sera from treated mice at termination (day 14) were screened for antibodies against secreted human apoE3 by Western blot analysis. In all five mice, anti-apoE antibodies were present, apparently at somewhat different amounts, being highest in mouse $\mathrm{D}$ and lowest in mouse $\mathrm{C}$, but were not detectable in the sera of control animals (Fig. 4d).

\section{Discussion}

Here, we report the first use of encapsulated cell technology to reverse hyperlipidaemia, which if successful in long term studies should stabilize or regress atherosclerotic lesions. Diverse viral and 
non-viral gene transfer strategies are being developed to express therapeutic proteins, but many problems remain. Increasingly, cell encapsulation technology is seen as an alternative possibility, particularly for patients with diabetes, neurodegenerative diseases (Alzheimer's and Parkinson's), or liver failure, and clinical trials are underway or planned $[21,27,28]$. The cell types tested include islets of Langerhans [29-31], hepatocytes [32,33], parathyroid cells [34] and dopamine-secreting cells [35,36], as well as cell lines genetically engineered to secrete bioactive proteins [37-41]. Although allogeneic cells minimize immune responses and obviate potential for xenogenic virus spread, use of xenogeneic cells is common. This includes clinical trials, for example, recombinant BHK cells to express human ciliary neurotrophic factor [23] and pancreatic or Sertoli cells from pigs to treat diabetes [42], while in rats a 2-year study to correct hypothyroidism using encapsulated pig parathyroid cells gave no immune responses or infections [43]. Alginate or agarose are the favoured polymers to produce permeable microcapsules, while thermoplastic materials are typically used for macrocapsule devices, such as hollow fibres or flat sheet membranes $[19,44]$.

Our study evaluated whether peritoneal implantation of alginate microencapsulated recombinant $\mathrm{CHO}$ cells could deliver therapeutic levels of human apoE3 protein to apoE ${ }^{-/-}$mice, a widely used model of hyperlipidaemia and atherosclerosis $[9,10,13,45]$. As a prerequisite, we injected CHO-cell derived apoE3 protein into their peritoneal cavities, as a bolus or repeated dose, and verified that apoE3 reached the plasma compartment. Moreover, the repeat intraperitoneal injection regime significantly reduced total cholesterol, whilst increasing the level of atheroprotective HDL. These findings agree with earlier data from intravenous bolus injections; total cholesterol fell by nearly 50\% at termination $(6 \mathrm{~h})$, attributed to increased hepatic clearance of cholesterol-rich remnant lipoproteins, while HDL increased by 10-18\% [46]. Why the HDL rises is unclear, although apoE can activate the cholesterol esterifying enzyme, LCAT, which is rate limiting for HDL maturation $[47,48]$. Additionally, marked reductions in VLDL and IDL may release apoA-I for HDL assembly [49].

Two different coatings were used to encapsulate CHO-E3 cells in alginate microspheres. One, poly-L-lysine, was initially studied in vitro using cells encapsulated at low density; after a short lag phase (days 1-4), perhaps an adaptation to the new environment, apoE secretion steadily increased as cells grew and divided in the Alg-PLL beads (days 5-10) before a plateau phase at confluence (days 11-15). Thereafter, secretion fell, presumably due to cell overgrowth and poor nutrient supply, but remained continuous at low level throughout the two-month study (Fig. 2b). One option to overcome excess cell proliferation, and diminished secretion, is to encapsulate recombinant mouse C2C12 myoblasts. These terminally differentiate into myotubes in low FCS, allowing implantation of non-dividing cells [50], although there is a need to increase expression by improving transfection vectors and to prevent immune responses [51,52]. 
The second coating, a polyethyleneimine-polybrene combination (PEI/PB) was chosen because PEI increases the mechanical stability of capsules [53,54], while the low molecular weight positively charged polybrene prevents cross-linking of individual microspheres by PEI. These AlgPEI/PB capsules secreted apoE3 at levels very similar to uncoated beads, suggesting that the coat had little effect on permeability. However, the beads differed markedly in stability, as judged by the abrasion test, since the uncoated capsules proved very fragile. Alg-PEI/PB performed slightly better than Alg-PLL in this test, and also appeared superior for cell growth since cell numbers increased 3.8-fold in Alg-PEI/PB beads compared to 2.8-fold in Alg-PLL .

Before studying encapsulated cells in vivo, we verified that the apoE secreted was biologically active. As apoE atheroprotection relates, in part, to its sequestration of cellular cholesterol [1,3,55], we examined this function by adding encapsulated CHO-E3 cell-conditioned medium to cells pre-labelled with $\left[{ }^{3} \mathrm{H}\right]$-cholesterol. This medium promoted 2-4-times more cholesterol efflux than control medium, confirming that secreted apoE3 was not inactivated during escape from the capsules. A pilot in vivo study was then carried out, implanting CHO-E3 cells encapsulated in Alg-PEI/PB beads into the peritoneum of three $\mathrm{apoE}^{-/-}$mice for 7 days. In two animals, apoE3 was detected in plasma and was accompanied by clear elevations in HDL and modest reductions in total cholesterol (13\% and 19\%). These changes were not seen in the third mouse and, when the capsules were retrieved, microscopy revealed that many were lysed and empty of cells. This explains why no apoE was detected in plasma, but not why breakage occurred since all mice received capsules from the same batch and these were microscopically intact preimplantation. Others have noted bead rupture [27,56], which is independent of the secreted protein or capsule coating, but although leakage of xenogeneic cells probably contributes to the overall inflammatory response, such cells are rapidly eliminated [23]. Some researchers omit liquefying the inner capsule with EGTA or citrate to minimize leakage, as this may promote instability. However, as a liquid inner alginate core provides more intracapsular space for cells to grow and nutrients to diffuse $[14,16]$, we preferred to retain this standard step, although future studies could consider omission if capsule instability remained a problem.

In a second in vivo study, CHO-E3 cells were encapsulated in Alg-PLL beads. ApoE3 was secreted in all five treated mice at least until day 7 post-implantation. Higher levels of plasma apoE3 were detected compared to the pilot study, perhaps because the beads were cultured longer before implantation, allowing the encapsulated cells more time to adapt and proliferate into their new environment. The larger pore size of Alg-PLL compared to Alg-PEI/PB may also be important because apoE3 is secreted as lipidated particles of heterogeneous size [57]; conceivably very large particles may not cross the alginate-polymer barrier [53]. Nevertheless, the amount of apoE3 was 
relatively low, with a peak of $154 \mathrm{ng} / \mathrm{ml}$ plasma compared to $\sim 50 \mu \mathrm{g} / \mathrm{ml}$ in normal mice [58,59]. This was not unexpected, however, as recombinant apoE is promptly sequestered by lipoproteins upon entry into the grossly hyperlipidaemic plasma of apoE-deficient mice, followed by rapid hepatic clearance of the particles [45]. Rapid removal has also been noted following apoE protein injections, both here (Fig. 1a,b) and by others [46]. In mouse, most liver-derived apoB is truncated (apoB-48, whereas human liver secretes only apoB-100), and as this variant structural protein for VLDL, IDL and LDL lacks the LDL-receptor binding domain, the particles require apoE for clearance [9,59], either via the LDL-receptor itself or LDL-receptor related protein (LRP) [2].

Despite low plasma apoE3, total cholesterol was significantly decreased by $25-30 \%$ on days 4 and 7, in addition to the rise in HDL. The threshold concentration of plasma apoE needed for cholesterol homeostasis is uncertain. The most detailed study, in which apoE $\mathrm{E}^{+/+}$bone marrow was mixed with apoE $\mathrm{E}^{-/-}$marrow in increasing amounts and then transplanted into apoE ${ }^{-/-}$recipient mice, suggests that $400 \mathrm{ng}$ apoE/ml is the lower limit to fully normalize plasma cholesterol [58]. In contrast, only $0.6 \mathrm{ng}$ apoE/ml is reported to maintain $40 \%$ reductions in plasma cholesterol for 16 weeks following intramuscular injection of an apoE3-expressing plasmid [60], while apoE3secreting endothelial cells embedded in Matrigel significantly lowered cholesterol levels by 40-60\% for over 3 months, even though apoE3 was not detected in plasma at any stage [45]. In our study, the mean reductions in plasma cholesterol at days 4 and 7 had rebounded at day 14 (Fig. 4a). One explanation, not discussed in the other studies [45,58,60], might be the appearance of antibodies against apoE3, a neo-antigen in apoE $\mathrm{E}^{-/-}$mice, which we detected in the sera of treated mice 14 days post-implantation. Indirect support for this possibility was our failure to detect apoE3 in plasma at day 14, despite finding that beads retrieved from the peritoneum continued to secrete apoE3 in vitro. This implies that apoE3 was continuously produced in the treated mice, but was neutralized by mouse anti-human apoE antibodies. Indeed, mouse $\mathrm{C}$, which gave the weakest immune response, showed no rebound of total cholesterol and in fact was lower on day 14 (253 $\mathrm{mg} / \mathrm{dl})$ than on day 7 (281 mg/dl). Note, however, that emergence of apoE antibodies is unlikely in alternative models that do not recognize apoE3 as foreign, including the double transgenic humanapoE2/apoE ${ }^{-/-}$ mouse, which mimics Type III hyperlipidaemia [61].

One factor promoting antibody emergence might be a non-specific host inflammatory reaction to capsule constituents, as signs of immunogenicity were noted at retrieval, including some lymphocyte and macrophage adhesion to the capsule surface and early fibrotic overgrowth (data not shown). This is important as fibrous tissue formation may physically impair effective secretion of therapeutic proteins, and also impede implant functioning by decreasing transfer of oxygen, nutrients and metabolites. Intraperitoneal inflammatory reactions against capsules most likely relate 
to alginate impurities, including pyrogens, endotoxins and mitogens, since ultrapure preparations can reduce fibrotic overgrowth to $<10 \%$ [62]. Such an adjuvant action of alginate beads might explain why secreted apoE was apparently inactivated in our study, whereas in the work cited above $[45,58,60]$ the hyperlipidaemia remained suppressed. On the other hand, gene transfer studies using viral vectors also report emergence of apoE antibodies in apoE $\mathrm{E}^{-/-}$mice, 2-4 weeks after exposure to the protein $[10,63,64]$, though this depends on the vector $[65,66]$ and the tissue targeted $[10]$.

In conclusion, we have shown for the first time that implantation of microencapsulated apoE-secreting cells can ameliorate hyperlipidaemia. Although our studies were short-term and designed only to demonstrate proof-of-principle, they also emphasize the need to improve capsule biocompatibility, a problem common to all encapsulated cell therapies. Difficulties of standardizing alginate purity and of producing uniform capsules appear readily soluble, the latter by the use of automated machines [67], while progress is being made in developing immune-compatible crosslinking coating polymers $[20,21,68]$. Other factors, such as choice of cell and site of transplantation are also under study [20,21]. Our hope is clear: that these advances will eventually allow routine encapsulated cell therapy in humans for short-term delivery of apoE3, pre- and post-angioplasty to protect against restenosis, and by analogy with conventional gene transfer approaches $[10,13,49,63$ $66]$, also for long-term delivery to stabilize or regress atherosclerotic lesions.

\section{Acknowledgements}

A.D.T. thanks the British Heart Foundation for a PhD Studentship (FS/97054) and we are grateful to GlaxoSmithKline for the provision of $\mathrm{apoE}^{-/-}$mice. 


\section{References}

[1] R.W. Mahley, S.C. Rall Jr. Apolipoprotein E: far more than a lipid transport protein. Annu. Rev. Genomics Hum. Genet. 1 (2001) 507-537.

[2] R.W Mahley, Z.S. Ji. Remnant lipoprotein metabolism: key pathways involving cell-surface heparan sulfate proteoglycans and apolipoprotein E. J. Lipid Res. 40 (1999) 1-16.

[3] K.H. Weisgraber. Apolipoprotein E: structure-function relationships. Adv. Protein Chem. 45 (1994) $249-302$.

[4] F.M. van Bockxmeer, C.D Mamotte, F.A. Gibbons, V. Burke, R.R. Taylor. Angiotensin-converting enzyme and apolipoprotein E genotypes and retenosis after coronary angioplasty. Circulation 92 (1995) 2066-2071.

[5] S.E. Humphries, P.J. Talmud, E. Hawe, M. Bolla, I.N. Day, G.J Miller. Apolipoprotein E4 and coronary heart disease in middle-aged men who smoke: a prospective study. Lancet 358 (2001) 115-119.

[6] N. Yamada, I Inoue, M. Kawamura, K. Harada, Y. Watanabe, H. Shimano, T. Gotoda, M. Shimada, K. Kohzaki, T. Tsukada, M. Shiomi, Y. Watanabe, Y. Yazaki. Apolipoprotein E prevents the progression of atherosclerosis in Watanabe heritable hyperlipidemic rabbits. J. Clin. Invest. 89 (1992) 706-711.

[7] H. Shimano, N. Yamada, M. Katsuki, M. Shimada, T. Gotoda, K. Harada, T. Murase, C. Fukazawa, F. Takaku, Y. Yazaki. Overexpression of apolipoprotein E in transgenic mice: marked reduction in plasma lipoproteins except high density lipoprotein and resistance against diet-induced hypercholesterolemia. Proc. Natl. Acad. Sci. USA 89 (1992) 1750-1754.

[8] K. Yamamoto, H. Shimano, M. Shimada, M. Kawamura, T. Gotoda, K. Harada, J. Ohsuga, Y. Yazaki, N. Yamada. Overexpression of apolipoprotein E prevents development of diabetic hyperlipidemia in transgenic mice. Diabetes 44 (1995) 580-585.

[9] J.A. Piedrahita, S.H. Zhang, J.R. Hagaman, P.M. Oliver, N. Maeda. Generation of mice carrying a mutant apolipoprotein E gene inactivated by gene targeting in embryonic stem cells. Proc. Natl. Acad. Sci. USA. 89 (1992) 4471-4475.

[10] J.D. Harris, I.R. Graham, S. Schepelmann, A.K. Stannard, M.L. Roberts, B.L. Hodges, V. Hill, A. Amalfitano, D.G. Hassall, J.S. Owen, G. Dickson. Acute regression of advanced and retardation of early aortic atheroma in immunocompetent apolipoprotein-E (apoE) deficient mice by administration of a second generation [E1(-), E3(), polymerase(-)] adenovirus vector expressing human apoE. Hum. Mol. Genet. 11 (2002) 43-58.

[11] A.L.Parker, C. Newman, S. Briggs, L. Seymour, P.J. Sheridan. Nonviral gene delivery: techniques and implications for molecular medicine. Expert Rev. Mol. Med. 5 (2003) 1-15.

[12] M.D. Brown, A.G. Schätzlein, I.F. Uchegbu. Gene delivery with synthetic (no viral) carriers. Int. J. Pharm. 229 (2001) 1-21.

[13] T. Athanasopoulos, J.S. Owen, D. Hassall, M.G. Dunckley, J. Drew, J. Goodman, A.D. Tagalakis, D.R. Riddell, G. Dickson. Intramuscular injection of a plasmid vector expressing human apolipoprotein E limits progression of xanthoma and aortic atheroma in apoE-deficient mice. Hum. Mol. Genet. 9 (2000) 2545-2551.

[14] I.T. Tai, A.M. Sun. Microencapsulation of recombinant cells: a new delivery system for gene therapy. FASEB J. 7 (1993) 1061-1069.

[15] R.P. Lanza, J.L. Hayes, W.L. Chick. Encapsulated cell technology. Nat. Biotechnol. 14 (1996) 1107-1111.

[16] P.L. Chang. Microcapsules as bio-organs for somatic gene therapy. Ann. N. Y. Acad. Sci. 831 (1997) $461-473$.

[17] T.M. Chang, S. Prakash. Therapeutic uses of microencapsulated genetically engineered cells. Mol. Med. Today 4 (1998) 221-227.

[18] M.J. Lysaght, P. Aebischer. Encapsulated cells as therapy. Sci. Am. 280 (1999) 52-58.

[19] P.L. Chang, J.M. Van Raamsdonk, G. Hortelano, S.C. Barsoum, N.C. MacDonald, T.L. Stockley The in vivo delivery of heterologous proteins by microencapsulated recombinant cells. Trends Biotechnol. 17 (1999) 78-83.

[20] G. Orive, R.M. Hernandez, A.R. Gascon, R. Calafiore, T.M. Chang, P. De Vos, G. Hortelano, D. Hunkeler, I. Lacik, A.M. Shapiro, J.L. Pedraz. Cell encapsulation: promise and progress. Nat. Med. 9 (2003) 104-107.

[21] G. Orive, R.M. Hernandez, A. Rodriguez Gascon, R. Calafiore, T.M. Chang, P. de Vos, G. Hortelano, D. Hunkeler, I. Lacik, J.L. Pedraz. History, challenges and perspectives of cell microencapsulation. Trends Biotechnol. 22 ( 2004) 87-92. 
[22] A.D. Tagalakis, I.R. Graham, D.R. Riddell, J.G. Dickson, J.S. Owen. Gene correction of the apolipoprotein (apo) E2 phenotype to wild-type apoE3 by in situ chimeraplasty. J. Biol. Chem. 276 (2001) 13226-13230.

[23] P. Aebischer, N.A. Pochon, B. Heyd, N. Deglon, J.M. Joseph, A.D. Zurn, E.E. Baetge, J.P. Hammang, M. Goddard, M. Lysaght, F. Kaplan, A.C. Kato, M. Schluep, L. Hirt, F. Regli, F. Porchet, N. De Tribolet. Gene therapy for amyotrophic lateral sclerosis (ALS) using a polymer encapsulated xenogenic cell line engineered to secrete hCNTF. Hum. Gene. Ther. 7 (1996) 851-860.

[24] S.J. Murdoch, W.C. Breckenridge. Development of a density gradient ultracentrifugation technique for the resolution of plasma lipoproteins which avoids apo E dissociation. Anal. Biochem. 222 (1994) 427-434.

[25] M.J. LaDu, T.M. Pederson, D.E. Frail, C.A. Reardon, G.S. Getz, M.T. Falduto. Purification of apolipoprotein E attenuates isoform-specific binding to beta-amyloid. J. Biol. Chem. 270 (1995) 9039-9042.

[26] J.V. Mulcahy, D.R. Riddell, J.S. Owen. Human scavenger receptor class B type II (SR-BII) and cellular cholesterol efflux. Biochem. J. 377 (2004) 741-747.

[27] P. Aebischer, M. Schluep, N. Deglon. Intrathecal delivery of CNTF using encapsulated genetically modified xenogeneic cells in amyotrophic lateral sclerosis patients. Nat. Med. 2 (1996) 696-699.

[28] C. Raoul, P. Aebischer. ALS, IGF-1 and gene therapy: 'it's never too late to mend'. Gene Ther. 11 (2004) 429430.

[29] K.A. Heald, T.R Jay, R. Downing. Prevention of antibody-mediated lysis of islets of Langerhans by alginate encapsulation: effect of capsule composition. Transplant. Proc. 26 (1994) 1103-1104.

[30] Y. Sun, X. Ma, D. Zhou, I. Vacek, A.M Sun. Normalization of diabetes in spontaneously diabetic cynomologus monkeys by xenografts of microencapsulated porcine islets without immunosuppression. J. Clin. Invest. 98 (1996) 1417-1422.

[31] P. Soon-Shiong. Treatment of type I diabetes using encapsulated islets. Adv. Drug Deliv. Rev. 35 (1999) $259-$ 270.

[32] A. Joly, J.F. Desjardins, B. Fremond. Survival, proliferation, and functions of porcine hepatocytes encapsulated in coated alginate beads: a step toward a reliable bioartificial liver. Transplantation 63 (1997) 795-803.

[33] Z.C. Liu, T.M. Chang. Coencapsulation of hepatocytes and bone marrow stem cells: in vitro conversion of ammonia and in vivo lowering of bilirubin in hyperbilirubemia Gunn rats. Int. J. Artif. Organs 26 (2003) 491497.

[34] C. Hasse, A. Zielke, G. Klock, A. Schlosser, P. Barth, U. Zimmermann, H. Sitter, W. Lorenz, M. Rothmund. Amitogenic alginates: key to first clinical application of microencapsulation technology. World J. Surg. 22 (1998) 659-665.

[35] P. Aebischer, P.A. Tresco, S.R. Winn, L.A. Greene, C.B. Jaeger. Long-term cross-species brain transplantation of a polymer-encapsulated dopamine-secreting cell line. Exp. Neurol. 111 (1991) 269-275.

[36] I. Date, T. Shingo, H. Yoshida, K. Fujiwara, K. Kobayashi, T. Ohmoto. Grafting of encapsulated dopaminesecreting cells in Parkinson's disease: long-term primate study. Cell Transplant. 9 (2000) 705-709.

[37] N. Deglon, B. Heyd, S.A. Tan, J.M. Joseph, A.D. Zurn, P. Aebischer. Central nervous system delivery of recombinant ciliary neurotrophic factor by polymer encapsulated differentiated C2C12 myoblasts. Hum. Gene Ther. 7 (1996) 2135-2146.

[38] W.T. Cheng, B.C. Chen, S.T. Chiou, C.M Chen. Use of nonautologous microencapsulated fibroblasts in growth hormone gene therapy to improve growth of midget swine. Hum. Gene Ther. 9 (1998) 1995-2003.

[39] G. Hortelano, N. Xu, A. Vandenberg, J. Solera, P.L. Chang, F.A. Ofosu. Persistent delivery of factor IX in mice: gene therapy for hemophilia using implantable microcapsules. Hum. Gene Ther. 10 (1999) 1281-1288.

[40] T. Joki, M. Machluf, A. Atala, J. Zhu, N.T. Seyfried, I.F. Dunn, T. Abe, R.S. Carroll, P.M. Black. Continuous release of endostatin from microencapsulated engineered cells for tumor therapy. Nat. Biotechnol. 19 (2001) 3539.

[41] T.A. Read, D.R. Sorensen, R. Mahesparan, P.O. Enger, R. Timpl, B.R. Olsen, M.H. Hjelstuen, O. Haraldseth, R. Bjerkvig. Local endostatin treatment of gliomas administered by microencapsulated producer cells. Nat. Biotechnol. 19 (2001) 29-34.

[42] R. Valdes. Xenotransplantation trials. Lancet 359 (2002) 2281.

[43] L. Lin, Y. Song, C. Song, P. Xu, C. Song. Successful xenotransplantation of microencapsulated newborn pig parathyroid cells in the treatment of hypoparathyroidism in rats. Chin. Med. J. (Engl) 116 (2003) 1161-1165. 
[44] H. Uludag, P. De Vos, P.A. Tresco. Technology of mammalian cell encapsulation. Adv. Drug Deliv. Rev. 35 (2000) 259-270.

[45] L. Cioffi, F.G. Sturtz, S. Wittmer, B. Barut, J. Smith-Gbur, V. Moore, T. Zupancic, B. Gilligan, R. Auerbach, F. Gomez, F. Chauvin, M. Antczak, D. Platika, H.R. Snodgrass. A novel endothelial cell-based gene therapy platform for the in vivo delivery of apolipoprotein E. Gene Ther. 6 (1999) 1153-1159.

[46] G. Wu, J. Yuan, D.B. Hunninghake. Effect of human apolipoprotein E isoforms on plasma lipids, lipoproteins and apolipoproteins in apolipoprotein E-deficient mice. Atherosclerosis 141 (1998) 287-296.

[47] O.L. Francone, M. Haghpassand, J.A. Bennett, L. Royer, J. McNeish. Expression of human lecithin:cholesterol acyltransferase in transgenic mice: effects on cholesterol efflux, esterification, and transport. J. Lipid Res. 38 (1997) 813-822.

[48] J.S. Owen, J.V. Mulcahy. ATP-binding cassette A1 protein and HDL homeostasis. Atheroscler. Suppl. 3 (2002) $13-22$.

[49] W.A. Boisvert, J. Spangenberg, L.K. Curtiss. Treatment of severe hypercholesterolemia in apolipoprotein Edeficient mice by bone marrow transplantation. J. Clin. Invest. 96 (1995) 1118-1124.

[50] E. Regulier, B.L. Schneider, N. Deglon, Y. Beuzard, P. Aebischer. Continuous delivery of human and mouse erythropoietin in mice by genetically engineered polymer encapsulated myoblasts. Gene Ther. 5 (1998) 10141022.

[51] G. Hortelano, N. Xu, A. Vandenberg, J. Solera, P.L. Chang, F.A. Ofosu. Persistent delivery of factor IX in mice: gene therapy for hemophilia using implantable microcapsules. Hum. Gene Ther. 10 (1999) 1281-1288.

[52] N. Deglon, V. Aubert, F. Spertini, L. Winkel, P. Aebischer. Presence of Gal-alpha1,3Gal epitope on xenogeneic lines: implications for cellular gene therapy based on the encapsulation technology. Xenotransplantation 10 (2003) 204-213.

[53] A. Gaumann, M. Laudes, B. Jacob, R. Pommersheim, C. Laue, W. Vogt, J. Schrezenmeir. Effect of media composition on long-term in vitro stability of barium alginate and polyacrylic acid multilayer microcapsules. Biomaterials 21 (2000) 1911-1917.

[54] D. Poncelet, T. Alexakis, B. Poncelet de Smet, R.J. Neufeld. Microencapsulation within crosslinked polyethyleneimine membranes. J. Microencapsul. 11 (1994) 31-40.

[55] Y. Huang, A. von Eckardstein, S. Wu, N. Maeda, G. Assmann. A plasma lipoprotein containing only apolipoprotein E and with gamma mobility on electrophoresis releases cholesterol from cells. Proc. Natl. Acad. Sci. USA. 91 (1994) 1834-1838.

[56] K.A. Heald, T.R. Jay, R. Downing. Assessment of the reproducibility of alginate encapsulation of pancreatic islets using the MTT colorimetric assay. Cell Transplant. 3 (1994) 333-337.

[57] A.K. Stannard, D.R. Riddell, S.M. Sacre, A.D Tagalakis, C. Langer, A. von Eckardstein, P. Cullen, T. Athanasopoulos, G. Dickson, J.S. Owen. Cell-derived apolipoprotein E (ApoE) particles inhibit vascular cell adhesion molecule-1 (VCAM-1) expression in human endothelial cells. J. Biol. Chem. 276 (2001) 46011-46016.

[58] A.H. Hasty, M.F. Linton, L.L. Swift, S. Fazio. Determination of the lower threshold of apolipoprotein E resulting in remnant lipoprotein clearance. J. Lipid Res. 40 (1999) 1529-1538.

[59] S.H. Zhang, R.L. Reddick, J.A. Piedrahita, N. Maeda. Spontaneous hypercholesterolemia and arterial lesions in mice lacking apolipoprotein E. Science 258 (1992) 468-471.

[60] M. Rinaldi, A.L. Catapano, P. Parrella, S.A. Ciafre, E. Signori, D. Seripa, P. Uboldi, R. Antonini, G. Ricci, M.G. Farace, V.M. Fazio. Treatment of severe hypercholesterolemia in apolipoprotein E-deficient mice by intramuscular injection of plasmid DNA. Gene Ther. 7 (2000) 1795-1801.

[61] B.J. van Vlijmen, K.W. van Dijk, H.B. van't Hof, P.J. van Gorp, A. van der Zee, H. van der Boom, M.L. Breuer, M.H. Hofker, L.M. Havekes. In the absence of endogenous mouse apolipoprotein E, apolipoprotein E*2(Arg158-->Cys) transgenic mice develop more severe hyperlipoproteinemia than apolipoprotein E*3-Leiden transgenic mice. J. Biol. Chem. 271 (1996) 30595-30602.

[62] R. van Schilfgaarde, P. De Vos. Factors influencing the properties and performance of microcapsules for immunoprotection of pancreatic islets. J. Mol. Med. 77 (1999) 199-205.

[63] K. Tsukamoto, P. Smith, J.M. Glick, D.J. Rader. Liver-directed gene transfer and prolonged expression of three major human ApoE isoforms in ApoE-deficient mice. J. Clin. Invest. 10 (1997) 107-114. 
[64] J.D. Harris, S. Schepelmann, T. Athanasopoulos, I.R. Graham, A.K. Stannard, Z. Mohri, V. Hill, D.G. Hassall, J.S. Owen, G. Dickson. Inhibition of atherosclerosis in apolipoprotein-E-deficient mice following muscle transduction with adeno-associated virus vectors encoding human apolipoprotein-E. Gene Ther. 9 (2002) 21-29.

[65] C. Desurmont, J.M. Caillaud, F. Emmanuel, P. Benoit, J.C. Fruchart, G. Castro, D. Branellec, J.M. Heard, N. Duverger. Complete atherosclerosis regression after human ApoE gene transfer in ApoE-deficient/nude mice. Arterioscler. Thromb. Vasc. Biol. 20 (2000) 435-442.

[66] I.H. Kim, A. Jozkowicz, P.A. Piedra, K. Oka, L. Chan. Lifetime correction of genetic deficiency in mice with a single injection of helper-dependent adenoviral vector. Proc. Natl. Acad. Sci. USA. 98 (2001) 13282-13287.

[67] A. Anilkumar, I. Lacik, T.G. Wang. A novel reactor for making uniform capsules. Biotechnol. Bioeng. 75 (2001) 581-589.

[68] G. Orive, R.M. Hernandez, A.R. Gascon, M. Igartua, J.L Pedraz. Development and optimisation of alginatePMCG-alginate microcapsules for cell immobilisation. Int. J. Pharm. 259 (2003) 57-68. 


\section{Legends to Figures}

Fig 1. Intraperitoneal apoE3 protein injections into apoE $\mathrm{E}^{-/-}$mice. (a) A bolus injection of apoE3 (50 $\mu \mathrm{g}$ ) gave measurable levels of apoE3 in plasma throughout the $24 \mathrm{~h}$ study, with a maximum between $2-4 \mathrm{~h}(\sim 6 \mu \mathrm{g} / \mathrm{ml})$. In a repeat dose regime, three mice received 4 daily intraperitoneal injections (50 $\mu \mathrm{g}$ apoE3) and plasma was analyzed at days 0, 2 and 5. (b) ApoE3 protein was readily detected $(0.25-0.85 \mu \mathrm{g} / \mathrm{ml})$ and produced a significant $\sim 25 \%$ reduction in cholesterol at termination $(P<0.05)$ (c), while levels of atheroprotective HDL rose $(P<0.05)(d)$.

Fig 2. In vitro expression and release of human apoE3 from encapsulated CHO-E3 cells. (a) Cells were cultured for 10 days after encapsulation at high density (12 x 106 cells) in Alg-PEI/PB or alginate only beads (uncoated) for 10 days. ApoE3 was secreted continuously at constant and comparable levels from both types of capsule. (b) CHO-E3 cells were encapsulated at low density (4 x $10^{6}$ cells) in Alg-PLL beads and cultured for 2 months. The cells remained viable and proliferated within the capsules, which showed no breakage. ApoE3 secretion increased to a maximum of $1 \mu \mathrm{g} / \mathrm{ml} / 24 \mathrm{~h}$ at days $11-15$, but steadily declined thereafter to $<20 \mathrm{ng} / \mathrm{ml} / 24 \mathrm{~h}$ at 2 months. (c) Blue-dextran (1\%) was incorporated inside uncoated and coated Alg-PLL and Alg$\mathrm{PEI} / \mathrm{PB}$ capsules, which were then tested for mechanical stability by vigorously shaking overnight with glass beads. Leakage from both coated beads was negligible $(<5 \%)$, as judged by $A_{620}$ measurements of supernatants, whereas uncoated capsules were very fragile. (d) To verify that secreted apoE3 was bioactive, cholesterol efflux studies were carried out. Wild-type CHO cells were pre-labelled with $\left[{ }^{3} \mathrm{H}\right]$-cholesterol and incubated with conditioned medium from encapsulated CHO-E3 cells for up to $8 \mathrm{~h}$. This medium promoted significantly more efflux at all time points compared to control medium. Results shown are mean \pm S.D. from triplicate samples. $* * P<0.01$, *** $P<0.001$.

Fig. 3. Peritoneal implantation of encapsulated CHO-E3 cells in apoE $\mathrm{E}^{-/-}$mice. In a pilot study, Alg$\mathrm{PEI} / \mathrm{PB}$ beads were injected into the peritoneal cavity of three $\mathrm{apoE}^{-/-}$mice (mice 1-3), collecting blood pre- and 2, 4 and 7 days post-implantation. (a) ApoE3 was detected in plasma of mice 2 and 3 (35-80 ng/ml), but not mouse 1. (b) Mice 2 and 3 showed reductions in plasma total cholesterol of $13 \%$ and $19 \%$, respectively, on day 7 compared to day, whereas (c) levels of atheroprotective HDL clearly rose at days 2 and 7 as judged by agarose gel electrophoresis; these changes were not seen in plasma from mouse 1. (d) When capsules were retrieved from the mice and cultured for 10 days they maintained their integrity and continuously secreted apoE3 during this period. Analysis 
of $24 \mathrm{~h}$ medium collections by Western blotting confirmed apoE3 secretion, although the signal for mouse 1 was weaker than for mice 2 and 3.

Fig. 4. Peritoneal implantation of encapsulated CHO-E3 cells produces a less atherogenic plasma lipid profile in apoE ${ }^{-/-}$mice. Alg-PLL microcapsules containing CHO-E3 cells were implanted into the peritoneum of five apoE ${ }^{-/-}$mice (A-E) for 2 weeks, collecting blood on days $0,4,7$ and 14, while other mice (a-e) received empty beads. (a) ApoE3 was detected in plasma of all treated mice on days 4 and $7(83 \pm 9$ and $153 \pm 14 \mathrm{ng} / \mathrm{ml})$, though not on day 14 ; this was confirmed (b) by Western blot analysis. Plasma total cholesterol was significantly lowered by $\sim 25 \%$ at days 4 and 7 , but had rebounded at day 14 (a), while agarose gel electrophoresis (c) revealed significant increases in the proportion of HDL present at days 4 and $7(P<0.05)$. (d) Sera from treated mice were screened for anti-apoE3 antibodies at termination (day 14). All five mice gave positive antibody responses, at somewhat different levels, but none was detectable in the sera of control animals. Con, control anti-apoE antibody. Where appropriate results are shown as means \pm S.D.; $* P<0.05$, $* * P<0.01$ and $* * * P<0.001$. 

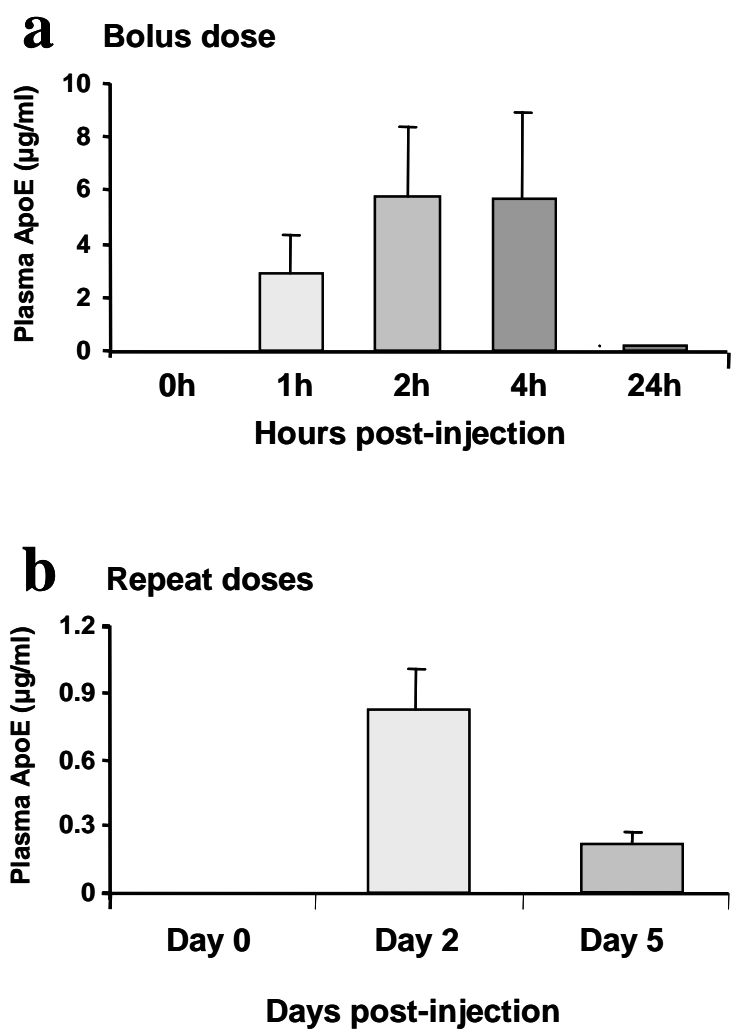

\section{C $\square$ Control $\square$ Treated}
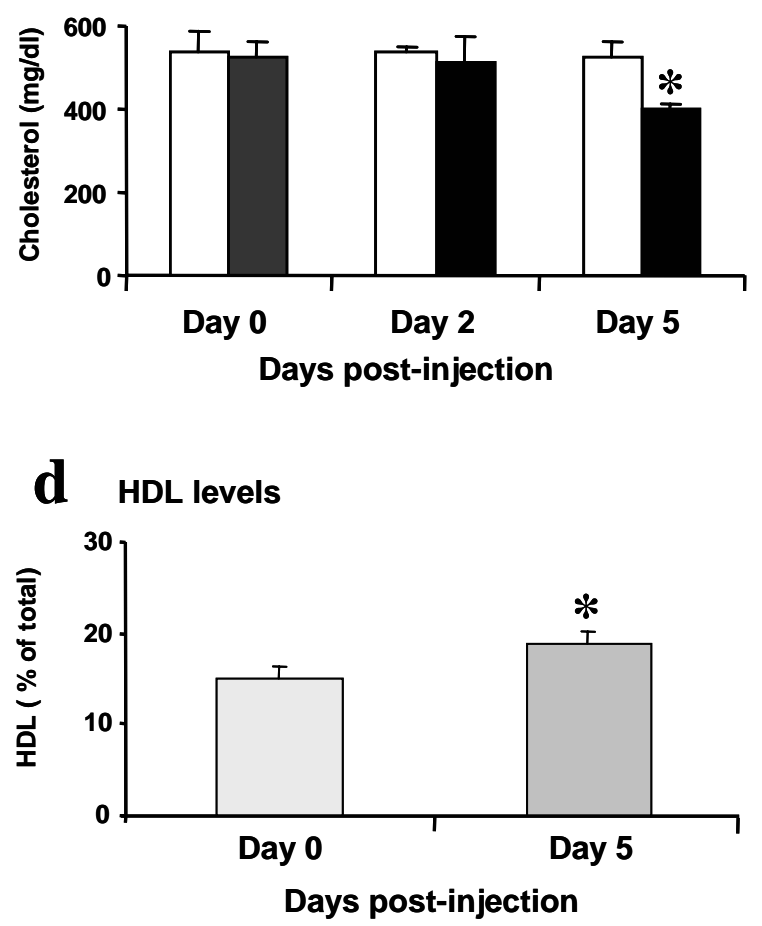
a $\square$ Uncoated $\square$ PEI/PB-coated

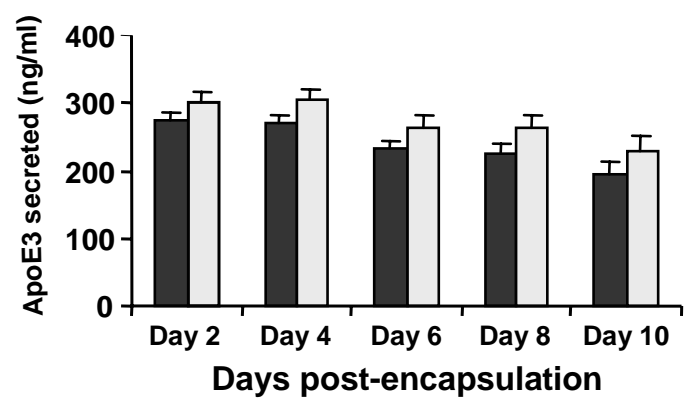

b PLL-coated

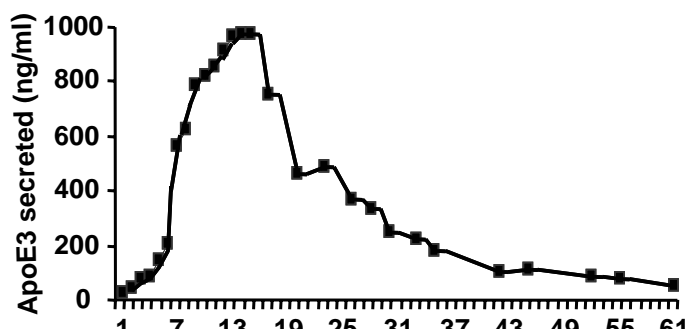

Days post-encapsulation

C Start $\square$ End
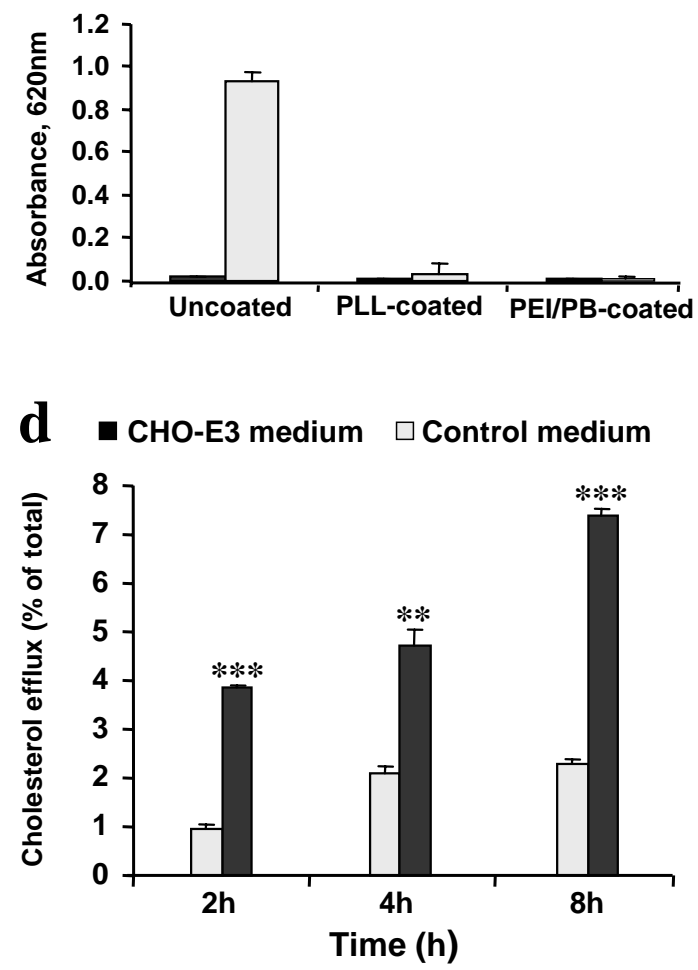
a $\quad-$ Mouse $1 \cdot \diamond \cdot \cdot$ Mouse $2-$ Mouse 3

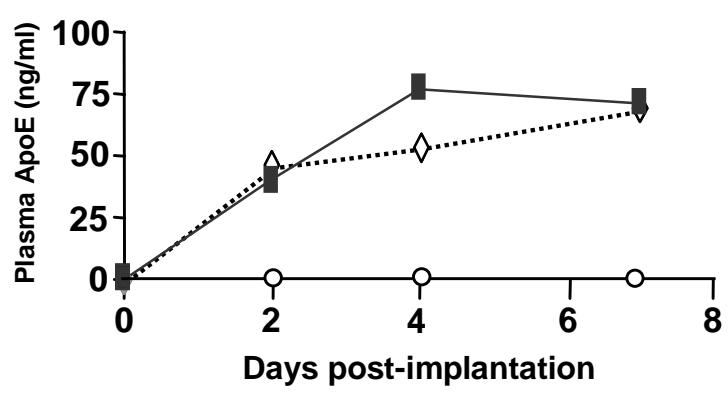

b - - Mouse $1 \cdot \checkmark \cdot \cdot$ Mouse $2-$ Mouse 3

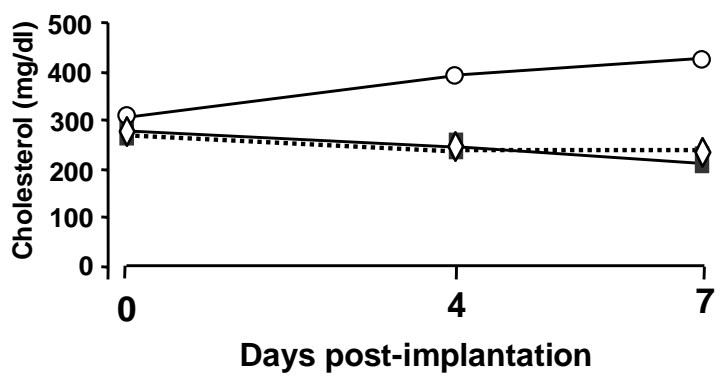

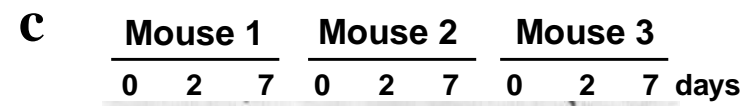

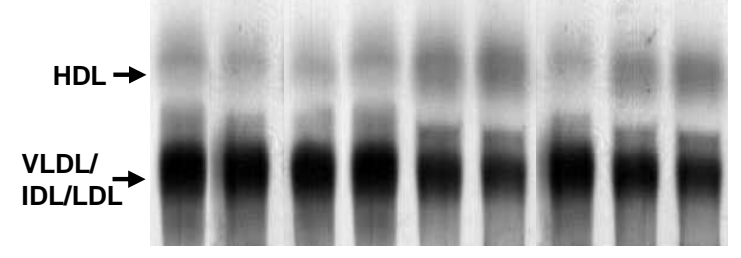

d Retrieved capsules

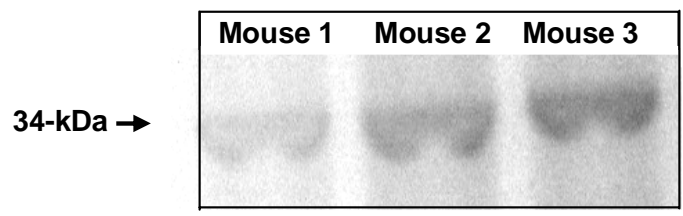




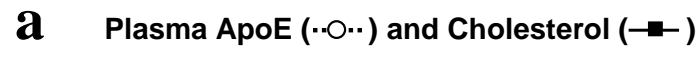

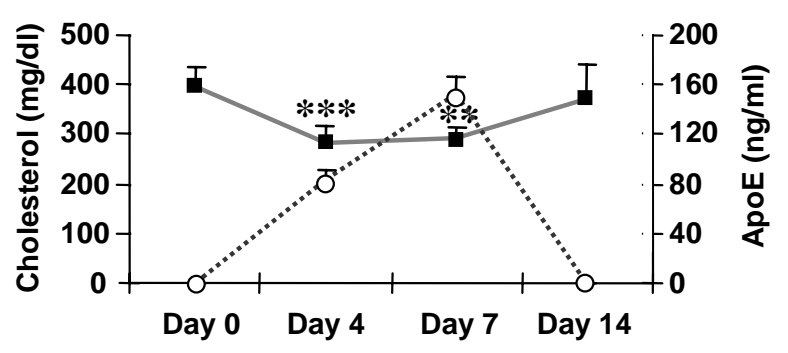

Days post-implantation

b Western blotting

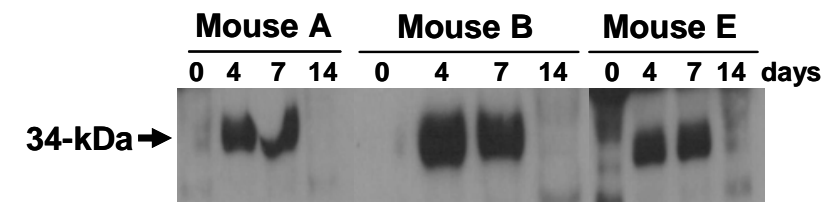

C HDL levels

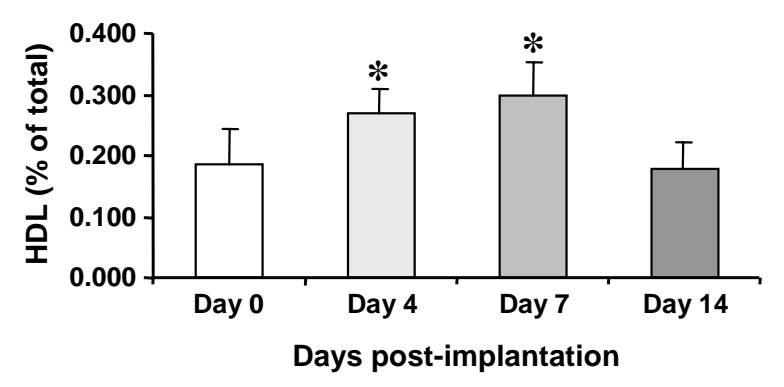

d Anti-apoE antibodies

Control Mice Treated Mice

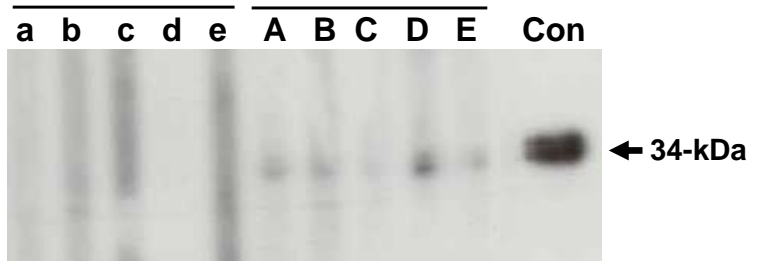

